\title{
REVIEW
}

\section{Cariprazine in Schizophrenia: Clinical Efficacy, Tolerability, and Place in Therapy}

Leslie Citrome

To view enhanced content go to www.advancesintherapy.com Received: December 13, 2012 / Published online: January 28, 2013 (C) Springer Healthcare 2013

\section{ABSTRACT}

Cariprazine is a dopamine D3-preferring D3/D2 receptor partial agonist in late-stage clinical development for the treatment of schizophrenia, as well as for bipolar disorder (manic/mixed and depressive episodes), and as an adjunctive agent for the treatment of major depressive disorder. Four phase 2 or 3, 6-week, randomized controlled trials in acute schizophrenia have been completed and reported as poster presentations or in press releases by the manufacturer. Superiority over placebo on the Positive and Negative Syndrome Scale total score was evidenced

\section{Citrome $(\bowtie)$}

Clinical Professor of Psychiatry \& Behavioral Sciences, New York Medical College, Valhalla, New York, USA 11 Medical Park Drive, Suite 106, Pomona, New York 10970, USA

e-mail: citrome@cnsconsultant.com

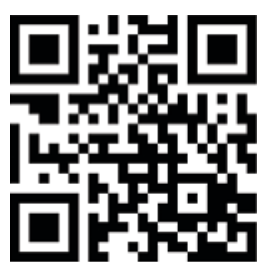

Enhanced content for Advances in Therapy articles is available on the journal web site: www.advancesintherapy.com for cariprazine in daily doses of $1.5,3.0$, $4.5,6.0,1.5-4.5,3.0-6.0$, and $6.0-9.0 \mathrm{mg}$. A randomized controlled trial for the prevention of relapse of schizophrenia is ongoing. In short-term, randomized controlled trials, cariprazine does not appear to adversely impact metabolic variables, prolactin, or the electrocardiogram (ECG) QT interval. In the fixed-dose study of cariprazine that tested $1.5,3.0$, and $4.5 \mathrm{mg} /$ day, the most commonly encountered adverse events were insomnia, extrapyramidal disorder, sedation, akathisia, nausea, dizziness, vomiting, anxiety, and constipation. However, the differences in incidence versus placebo for these events were generally small. If approved by regulatory authorities, cariprazine would join aripiprazole as the second dopamine receptor partial agonist antipsychotic available for clinical use. Cariprazine differs from aripiprazole in terms of dopamine D3 receptor selectivity. Further studies would be helpful to discern the distinguishing features of cariprazine from other second-generation antipsychotics.

Keywords: Antipsychotic; Cariprazine; Dopamine partial agonist; Dosing; Efficacy; Schizophrenia; Tolerability 


\section{INTRODUCTION}

A major challenge in the treatment of schizophrenia is the heterogeneity of antipsychotic response, both in terms of efficacy and tolerability [1]. The adage of "one size fits all" has no place in the contemporary management of this chronic and disabling disorder. Thus, when new antipsychotic medications become available, an individual with schizophrenia will have another option to try that may be more helpful for them in terms of reducing symptoms, be more easily tolerated, lead to improved adherence, and ultimately lead to superior outcomes. Unfortunately, there is no available technique that will predict which patient will respond to what antipsychotic and, thus, empirical trials of one medication after another is the usual course of events.

The antipsychotics themselves have differing pharmacodynamic properties that usually translate to small differences in efficacy and large differences in tolerability profiles when comparing groups of individuals. With regard to the tolerability differences, each antipsychotic option has its own profile of most commonly encountered adverse events, and this can be a starting point to tailor choices consistent with an individual's values and preferences, assuming adequate efficacy for that person [1].

In the US, several first-line, second-generation antipsychotics are now available as generic products - risperidone, olanzapine, quetiapine (in the immediate-release formulation), and ziprasidone. The other available secondgeneration antipsychotics, aripiprazole, paliperidone, iloperidone, asenapine, and lurasidone, are branded and relatively more expensive, but represent additional treatment options that together with ziprasidone have a smaller impact on weight and metabolic variables than some of the older agents in the class. These "metabolically-friendlier" secondgeneration antipsychotics differ in several important ways, including requirements for titration, dosing frequency, meal requirements, sedation profile, extrapyramidal symptoms (EPS)/akathisia profile, effects on prolactin, potential effects on the electrocardiogram (ECG) QT interval, and the availability of additional formulations and indications [2].

Cariprazine is a new second-generation antipsychotic in late-stage of clinical development for the treatment of schizophrenia, as well as for bipolar disorder (manic/mixed and depressive episodes) and as an adjunctive agent for the treatment of major depressive disorder. The intent of this review is to describe the efficacy, tolerability, and potential place in therapy of cariprazine for the treatment of schizophrenia.

A PubMed search was conducted on October 312012 using the search terms "cariprazine," "RGH-188," and "RGH 188" without any date or language restrictions. The resulting 15 publications and their reference lists were then specifically examined for primary sources of information with emphasis on the use of cariprazine in persons with schizophrenia. A query of the ClinicalTrials.gov website on October 312012 yielded 18 separate records and provided additional information regarding registered trials of cariprazine. The abstract books for the annual scientific meetings of the American Psychiatric Association (20082012) [3-7], Institute on Psychiatric Services of the American Psychiatric Association (20082012) [8-12], New Clinical Drug Evaluation Unit (2008-2012) [13-17], and American College of Neuropsychopharmacology (20082011) [18-21] were also examined and yielded additional relevant data that have not yet been published as full reports in peer-refereed 
journals. Whenever possible, reproductions of the poster presentations were obtained in digital PDF format from the authors. Press releases from the manufacturer were also reviewed for preliminary clinical trial results that have not yet been presented at scientific meetings. A similar search strategy has been used by the author in other reviews of cariprazine, including a companion review regarding cariprazine for the treatment of bipolar disorder [22], and a systematic review with emphasis on the chemistry, pharmacodynamics, and pharmacokinetics of cariprazine [23]. A complete list of all clinical trials for cariprazine as registered on the ClinicalTrials.gov website is available in the latter review [23].

\section{PHARMACODYNAMICS AND PHARMACOKINETICS}

Cariprazine is a dopamine D3-preferring, D3/D2 receptor partial agonist. The in vitro binding of cariprazine was highest for human dopamine D3 receptors (Ki $0.085 \mathrm{nM}$ ), followed by affinity for both D2L and D2S subtypes of human D2 receptors (Ki $0.49 \mathrm{nM}$ and $0.69 \mathrm{nM}$, respectively) (Table 2 in [24]). Aripiprazole is also a dopamine receptor partial agonist but although it shares with cariprazine similar D2 receptor binding affinity, cariprazine has more robust D3 antagonist-partial agonist affinity and 3- to 10-fold greater D3 versus D2 selectivity [24]. The D3 receptor is an autoreceptor that controls the phasic, but not tonic, activity of dopamine

Table 1 Summary of double-blind, randomized efficacy trials of cariprazine for schizophrenia, as conducted by the manufacturer. All are 6 weeks in duration unless otherwise noted

\begin{tabular}{|c|c|c|c|c|c|c|}
\hline Study & Phase & $N$ & $\begin{array}{l}\text { Cariprazine daily dose/ } \\
\text { dose ranges }(N)\end{array}$ & $\begin{array}{l}\text { Active control daily } \\
\text { dose }(N)\end{array}$ & $\begin{array}{l}\text { Placebo } \\
(N)\end{array}$ & Comments \\
\hline $\begin{array}{l}\text { RGH-MD-03 } \\
{[37]}\end{array}$ & 2 & 392 & $\begin{array}{l}1.5-4.5 \mathrm{mg}(128) ; \\
6.0-12.0 \mathrm{mg}(134)\end{array}$ & None & 130 & $\begin{array}{l}\text { Unpublished. Presented } \\
\text { as a poster. }\end{array}$ \\
\hline $\begin{array}{l}\text { RGH-MD-16 } \\
{[38]}\end{array}$ & 2 & 732 & $\begin{array}{l}1.5 \mathrm{mg}(145) ; 3.0 \mathrm{mg} \\
(147) ; 4.5 \mathrm{mg}(148)\end{array}$ & $\begin{array}{l}\text { Risperidone } 4.0 \mathrm{mg} \\
(141)\end{array}$ & 151 & $\begin{array}{l}\text { Unpublished. Presented } \\
\text { as a poster. An open-label } \\
\text { extension to this study was } \\
\text { also completed and data } \\
\text { presented as a poster [ } 41] \text {. }\end{array}$ \\
\hline $\begin{array}{l}\text { RGH-MD-04 } \\
\text { [39] }\end{array}$ & 3 & 617 & $\begin{array}{l}3.0 \mathrm{mg}(\mathrm{ND}) ; 6.0 \mathrm{mg} \\
(\mathrm{ND})\end{array}$ & $\begin{array}{l}\text { Aripiprazole } 10 \mathrm{mg} \\
\text { (ND) }\end{array}$ & ND & $\begin{array}{l}\text { Unpublished. Limited } \\
\text { information is available in } \\
\text { a press release. }\end{array}$ \\
\hline $\begin{array}{l}\text { RGH-MD-05 } \\
{[39]}\end{array}$ & 3 & 446 & $\begin{array}{l}3.0-6.0 \mathrm{mg}(\mathrm{ND}) \\
6.0-9.0 \mathrm{mg}(\mathrm{ND})\end{array}$ & None & ND & $\begin{array}{l}\text { Unpublished. Limited } \\
\text { information is available in } \\
\text { a press release. }\end{array}$ \\
\hline $\begin{array}{l}\text { RGH-MD-06 } \\
{[40]}\end{array}$ & 3 & $\sim 900$ & $3.0-9.0 \mathrm{mg}(\mathrm{NA})$ & None & NA & $\begin{array}{l}\text { Ongoing long-term relapse } \\
\text { prevention study. See } \\
\text { NCT01412060 on the } \\
\text { Clinical Trials.gov website. }\end{array}$ \\
\hline
\end{tabular}

There is one additional study that was conducted in Japan and was a 2-week phase 2 exploratory study [42]. Results have not been publically disclosed

$N A$ not applicable, $N D$ not disclosed 
Table 2 Treatment-emergent adverse events with an incidence at least $5 \%$ for any of the active treatment arms and at least twice that for placebo from RGH-MD-16 [38] - incidence (\%) and NNH versus placebo

\begin{tabular}{|c|c|c|c|c|c|c|c|c|c|}
\hline \multirow[t]{3}{*}{ Adverse event } & \multirow{3}{*}{$\begin{array}{l}\text { Placebo } \\
(n=151) \\
\%\end{array}$} & \multicolumn{6}{|c|}{ Cariprazine } & & \\
\hline & & \multicolumn{2}{|c|}{$\begin{array}{l}1.5 \mathrm{mg} / \mathrm{day} \\
(n=145)\end{array}$} & \multicolumn{2}{|c|}{$\begin{array}{l}3.0 \mathrm{mg} / \text { day } \\
(n=146)\end{array}$} & \multicolumn{2}{|c|}{$\begin{array}{l}4.5 \mathrm{mg} / \text { day } \\
(n=147)\end{array}$} & \multicolumn{2}{|c|}{$\begin{array}{l}\text { Risperidone } \\
(n=140)\end{array}$} \\
\hline & & $\%$ & $\mathrm{NNH}$ & $\%$ & NNH & $\%$ & NNH & $\%$ & NNH \\
\hline Insomnia & 7 & 10 & 34 & 16 & 12 & 16 & 12 & 15 & 13 \\
\hline Extrapyramidal disorder & 5 & 9 & 25 & 9 & 25 & 12 & 15 & 13 & 13 \\
\hline Sedation & 3 & 5 & 50 & 5 & 50 & 8 & 20 & 11 & 13 \\
\hline Akathisia & 5 & 9 & 25 & 10 & 20 & 8 & 34 & 9 & 25 \\
\hline Nausea & 3 & 5 & 50 & 8 & 20 & 8 & 20 & 6 & 34 \\
\hline Dizziness & 2 & 3 & 100 & 2 & ND & 6 & 25 & 6 & 25 \\
\hline Vomiting & 3 & 3 & ND & 6 & 34 & 5 & 50 & 3 & ND \\
\hline Anxiety & 3 & 4 & 100 & 6 & 34 & 5 & 50 & 2 & NA \\
\hline Constipation & 3 & 10 & 15 & 6 & 34 & 5 & 50 & 9 & 17 \\
\hline Tremor & 3 & 3 & ND & 4 & 100 & 2 & $\mathrm{NA}$ & 7 & 25 \\
\hline Weight increased & 1 & 2 & 100 & 3 & 50 & 0 & NA & 5 & 25 \\
\hline
\end{tabular}

As noted in the text regarding study RGH-MD-03 [37], incidence of akathisia was 1\% for subjects receiving placebo, 10\% for cariprazine $1.5-4.5 \mathrm{mg} /$ day, and $9 \%$ for cariprazine $6.0-12.0 \mathrm{mg} /$ day, yielding $\mathrm{NNH}$ values versus placebo of 12 and 13 for low-dose and high-dose cariprazine, respectively. Incidence of extrapyramidal disorder was $5 \%$ for subjects receiving placebo, $6 \%$ for cariprazine $1.5-4.5 \mathrm{mg} /$ day, and $10 \%$ for cariprazine $6.0-12.0 \mathrm{mg} /$ day, yielding $\mathrm{NNH}$ values versus. placebo of 100 and 20 for low-dose and high-dose cariprazine, respectively

$N A$ not applicable as placebo rate is greater than drug rate, $N D$ no difference from placebo, $N N H$ number needed to harm

neurons and is thought to mediate behavioral abnormalities elicited by glutamate/N-MethylD-aspartic acid (NMDA) receptor blockade [25]. Animal studies have demonstrated pro-cognitive effects potentially attributable to dopamine D3 preferring agents [26, 27].

Cariprazine also has high binding affinity for human serotonin 5-HT2B receptors (Ki $0.58 \mathrm{nM}$ ) (Table 2 in [24]). Activity at these receptors may modulate dopamine release in the nucleus accumbens [28]. Cariprazine has more moderate affinity for human 5-HT1A receptors (Ki $3 \mathrm{nM}$ ) and acts as a partial agonist at this receptor [24]. Theoretically, this may be associated with beneficial effects on negative symptoms and cognitive dysfunction, as observed in preclinical studies [29, 30]. Affinity at other receptors is weaker. This includes human 5-HT2A (Ki 19 nM), histamine H1 (Ki $23 \mathrm{nM}), 5-\mathrm{HT} 7$ (111 nM), and 5-HT2C (134 nM) receptors. Low affinity was observed for all tested adrenergic receptors [24]. This profile differs from that of aripiprazole, where aripiprazole bound more potently than cariprazine to rat striatal dopamine D2, human and rat 5-HT2A, 5-HT2C, and adrenergic receptors [24].

In a study of male subjects with schizophrenia, positron emission tomography (PET) scans of dorsal striatal regions (caudate nucleus and putamen) and ventral striatum (nucleus accumbens) showed after 14 days 
of cariprazine $1.5 \mathrm{mg} /$ day, dopamine D2/D3 receptor occupancy of $69 \%$ in the caudate nucleus, $69 \%$ in the nucleus accumbens, and $75 \%$ in the putamen [31, 32]. After 14 days of cariprazine $3 \mathrm{mg} /$ day, maximum occupancy ( $\geq 90 \%$ ) was observed [31, 32].

The pharmacokinetics of cariprazine was tested in small short-term studies in both healthy volunteers [33] and in subjects with schizophrenia [34, 35], with similar results [35]. Maximum concentration is observed in 3-4 h under fasting conditions, with food causing a slight delay but no significant effect on the extent of absorption. The mean half-life for cariprazine was 2-5 days over a dose range of 1.5-12.5 mg in the subjects with schizophrenia [34]. Cariprazine is metabolized by cytochrome P450 3A4 and, to a lesser extent, by cytochrome P450 2D6 [36]. Following multiple administrations, there was marked accumulation in plasma concentrations for cariprazine and its metabolites, desmethylcariprazine and didesmethyl-cariprazine. Systemic exposure to desmethyl-cariprazine was $30-40 \%$ of cariprazine, and was dose proportional. Didesmethyl-cariprazine's half-life is substantially longer than that for cariprazine, and in the study of healthy volunteers the half-life was observed to be 2-3 weeks [33]; thus, systemic exposure to didesmethyl-cariprazine was several times higher than that for cariprazine [34, 35]. Steady state was achieved within the dosing duration of 3 weeks for cariprazine and desmethyl-cariprazine, but not for didesmethylcariprazine [34, 35].

\section{SHORT-TERM CLINICAL TRIALS}

\section{Overview}

Results from two phase 2 and two phase 3 , shortterm, randomized controlled trials of cariprazine in subjects with schizophrenia have been reported in posters at scientific meetings $[37,38]$ and in a press release from the manufacturer [39]. Table 1 [37-42] provides an overview of studies RGH-MD-03 [37], RGH-MD-16 [38], RGH-MD-04 [39], and RGH-MD-05 [39]. In all of the studies, subjects could receive up to 6 weeks of randomized treatment. The primary efficacy measure was the Positive and Negative Syndrome Scale (PANSS) total score; the primary outcome was change from baseline on the PANSS total score at the 6-week endpoint. Figure 1 [37-39] provides an overview of the PANSS total score difference from placebo at endpoint for the four studies. All cariprazine treatment arms were statistically superior to placebo on the primary outcome, with the exception of the high-dose treatment arm (6.0-12.0 mg/day) in RGH-MD-03, the proofof-concept phase 2 study that enrolled the least number of subjects.

\section{RGH-MD-03}

This flexible-dose study was conducted in 34 US sites [37]. Inclusion criteria included a diagnosis of schizophrenia, current psychotic episode less than 4 weeks in duration, 18-65 years of age, PANSS total score of 80-120, and a Clinical Global Impressions-Severity (CGI-S) score of $\geq 4$. After up to 7 days of a washout off medications in an inpatient setting, 392 subjects were randomized (safety population included 389 subjects) to "low-dose" cariprazine, "high-dose" cariprazine, or placebo. Subjects randomized to low-dose cariprazine received 1.5 $\mathrm{mg}$ /day on days 1 and 2, 1.5-3.0 mg/day on days 3 and 4 , and $1.5-4.5 \mathrm{mg} /$ day as of day 5 . Subjects randomized to high-dose cariprazine received $1.5 \mathrm{mg} /$ day on days 1 and 2, $3.0 \mathrm{mg} /$ day on days 3 and 4, 3.0-6.0 mg/day on days 5 and 6, 3.0-9.0 $\mathrm{mg}$ /day on days 7 and 8 , and $6.0-12.0 \mathrm{mg}$ /day as of day 9 . Hospitalization was mandatory during 


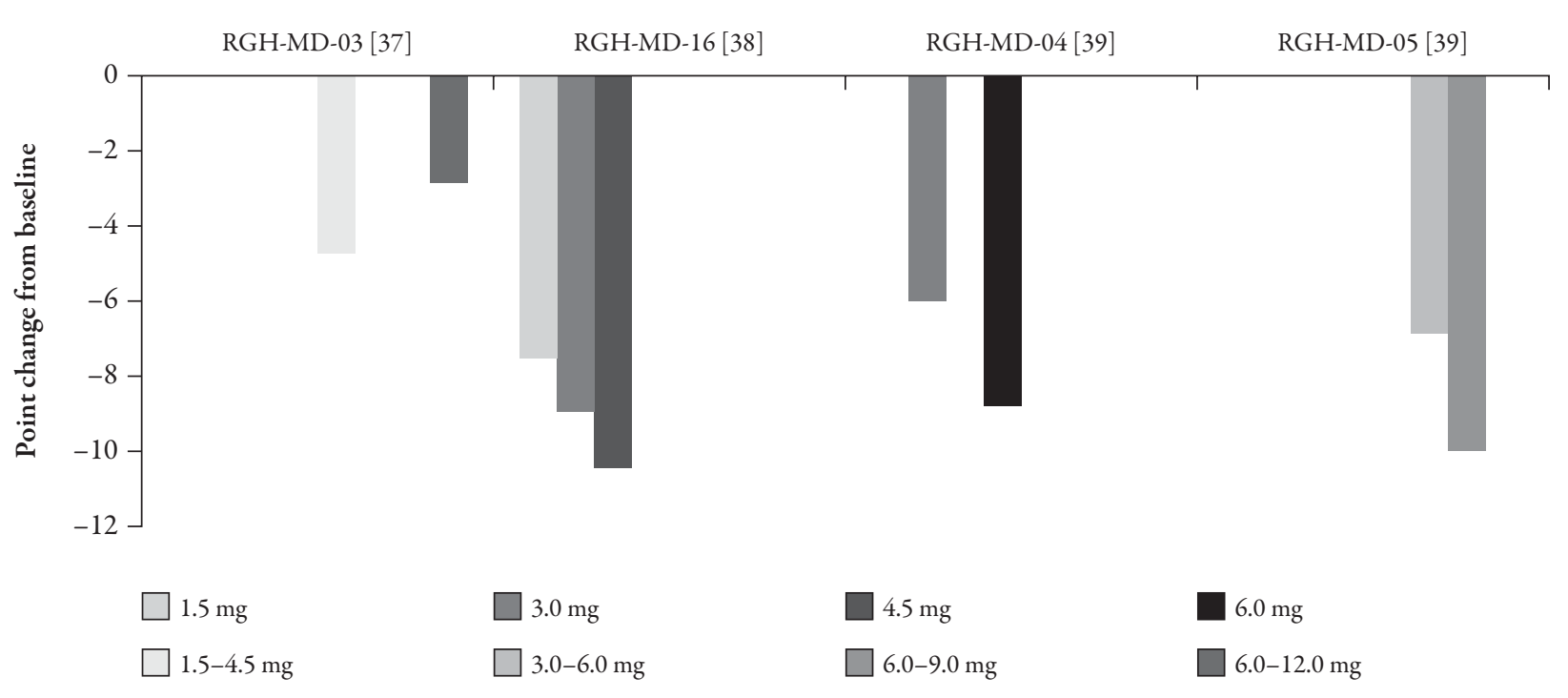

Fig. 1 Cariprazine efficacy outcomes: Positive and Negative Syndrome Scale total score difference from placebo, by study and daily dose, for four 6-week, randomized controlled trials. All cariprazine arms, except for 6.0-12.0 mg in RGH-MD-03, were statistically significantly superior to placebo (see text). Active controls were used in RGH-MD-16 (risperidone $4.0 \mathrm{mg} /$ day, change from placebo approximately 15 points as measured from Fig. 1 in [38]) and RGH-MD-04 (aripiprazole, change not disclosed in [39]). Last observation carried forward was used in RGH-MD-03 and RGH-MD-04. Mixed models for repeated measures used for RGH-MD-04 and RGH-MD-05

screening and the first 3 weeks of double-blind treatment. Mean age of subjects ranged from 40 to 42 years across the three treatment arms; male gender ranged from $76 \%$ to $83 \%$; body mass index (BMI) ranged from 28 to $29 \mathrm{~kg} / \mathrm{m}^{2}$; and baseline PANSS total score ranged from 94 to 96. A total of $46 \%$ patients discontinued the trial prematurely (same proportion for all treatment arms). Adverse events leading to discontinuation were $15 \%, 9 \%$, and $8 \%$ for placebo, low-dose, and high-dose groups, respectively; primarily for worsening of schizophrenia. For the primary efficacy parameter, the overall $P$ value comparing the three treatment groups was not statistically significant $(P=0.10)$. Pairwise comparison between each cariprazine dose group and placebo yielded nominal (without multiplicity adjustment) significant superiority for the low-dose group but not for the high-dose group. Low-dose cariprazine showed nominal (without multiplicity adjustment) statistical superiority versus placebo in PANSS negative score starting at week 1 and continuing until the end of the study. Treatment-emergent adverse events with an incidence of at least 10\% for any of the cariprazine treatment arms and at least twice that for placebo were akathisia (low-dose cariprazine: 10\%, high-dose cariprazine: 9\%, placebo: $1 \%$ ) and extrapyramidal disorder (lowdose cariprazine: $6 \%$, high-dose cariprazine: 10\%, placebo: $5 \%$ ). No clinically meaningful changes in fasting serum glucose, serum lipid levels, and prolactin level were reported.

\section{RGH-MD-16}

This fixed-dosed study was conducted internationally and 38\% of subjects were enrolled in the US [38]. Inclusion criteria included a diagnosis of schizophrenia, 
current psychotic episode less than 2 weeks in duration, 18-60 years of age, PANSS total score of $80-120$, a rating of $\geq 4$ (moderate or higher) on at least two of the four PANSS positive items of delusions, hallucinatory behavior, conceptual disorganization, and suspiciousness/ persecution, and a CGI-S score of $\geq 4$. A total of 732 subjects (729 in the safety population) were randomized to cariprazine $1.5,3.0$, or $4.5 \mathrm{mg}$ /day, risperidone $4.0 \mathrm{mg} /$ day, or placebo. The starting dose of cariprazine was $1.5 \mathrm{mg}$ /day; dosages increased in increments of $1.5 \mathrm{mg} /$ day for subjects randomized to $3 \mathrm{mg} /$ day (day 2) or $4.5 \mathrm{mg} /$ day (day 3). The starting dose of risperidone was $2 \mathrm{mg} /$ day and titrated to $4 \mathrm{mg} /$ day on day 3 . Subjects were required to be hospitalized during the washout/screening period and for the first 4 weeks of double-blind treatment; on day 28 and thereafter, patients could be discharged if their CGI-S score was no greater than 3, posed no significant risk of suicide or violent behavior, and were deemed ready for discharge. Mean age of subjects ranged from 36 to 37 years across the five treatment arms; male gender ranged from $64 \%$ to $73 \%$; white race ranged from $48 \%$ to $53 \%$; mean duration of schizophrenia ranged from 11 to 12 years; and baseline PANSS total score ranged from 97 to 98 . A total of $36 \%$ discontinued the trial prematurely (range $28-48 \%$ across the treatment arms). Adverse events leading to discontinuation were $15,10,6,8$, and $9 \%$ for placebo, cariprazine $1.5,3.0$, and $4.5 \mathrm{mg} /$ day, and risperidone, respectively; usually for worsening of schizophrenia, psychotic disorder, and psychotic behavior. On PANSS total score, statistically significant improvements were seen for each cariprazine dose group and for risperidone relative to placebo. Significant improvement at week 6 for cariprazine and risperidone versus placebo was also seen on the CGI-S. Cariprazine (and risperidone) were statistically significantly superior to placebo on positive (PANSS Positive subscale) and negative (PANSS Negative subscale and Negative Symptom Assessment [NSA-16]) symptoms of schizophrenia. Clinical Global Impressions-Improvement (CGI-I) scores at week 6 demonstrated superior improvement for each of the cariprazine treatment arms and for risperidone versus placebo. In general, improvements on each of the efficacy outcomes were numerically higher for cariprazine $4.5 \mathrm{mg} /$ day, followed by 3.0 and $1.5 \mathrm{mg} /$ day. The efficacy outcomes were numerically highest for risperidone. Treatment-emergent adverse events with an incidence at least 5\% for any of the cariprazine treatment arms and at least twice that for placebo were insomnia, extrapyramidal disorder, sedation, akathisia, nausea, dizziness, vomiting, anxiety, and constipation. None of the treatment-emergent adverse events yielded number-needed-to-harm (NNH) values $<10$ for any of the cariprazine doses tested; see Table $2[37,38]$. EPS-related adverse events (as opposed to the more restrictive adverse event term "extrapyramidal disorder") were reported by $21 \%, 22 \%, 22 \%$, and $29 \%$ of cariprazine $1.5,3.0$, and $4.5 \mathrm{mg} /$ day, and risperidone subjects, respectively, versus $13 \%$ for placebo subjects. This yields a NNH versus placebo of $13,12,12$, and 7 for cariprazine 1.5, 3.0, and $4.5 \mathrm{mg} / \mathrm{day}$, and risperidone subjects, respectively. No clinically meaningful changes in metabolic variables, prolactin elevation, or QTc prolongation (>500 $\mathrm{msec}$ ) were observed for cariprazine. Potentially clinically significant weight gain ( $\geq 7 \%$ increase from baseline) was greater for risperidone $(16.7 \%)$ than cariprazine $(8.5 \%, 10.7 \%$, and $4.9 \%$ for $1.5,3.0$, and 4.5 $\mathrm{mg} /$ day, respectively) or placebo $(2 \%)$, yielding a NNH versus placebo of $16,12,35$, and 7 for cariprazine $1.5,3.0$, and $4.5 \mathrm{mg} / \mathrm{day}$, and risperidone subjects, respectively. 


\section{RGH-MD-04}

This fixed-dosed study was conducted internationally [39]. Inclusion criteria included a diagnosis of schizophrenia, 18-60 years of age, and a PANSS total score of 80-120. A total of 617 subjects were randomized to one of the following treatments arms: cariprazine $3.0 \mathrm{mg} /$ day, cariprazine $6.0 \mathrm{mg} /$ day, aripiprazole $10 \mathrm{mg} /$ day, or placebo. Subjects were required to be hospitalized during the washout period and for the first 4 weeks of the double-blind treatment; afterwards they could be discharged from the hospital as determined by the site investigator and based on the patient's clinical status. A total of $33 \%$ of patients discontinued prematurely. Statistically significant improvement in PANSS total score was observed in each of the cariprazine dose groups relative to placebo. Moreover, the change from baseline in PANSS total score was statistically significant at every time point starting at week 1 for cariprazine $6.0 \mathrm{mg}$ /day and week 3 onwards for the cariprazine $3.0 \mathrm{mg} /$ day. Statistically significant improvements were also seen in the aripiprazole group relative to placebo in the PANSS total score at each week. The most common adverse events (incidence of at least $10 \%)$ observed in any treatment were akathisia, insomnia, and headache.

\section{RGH-MD-05}

This fixed-flexible dose study was conducted internationally [39]. Inclusion criteria included a diagnosis of schizophrenia, 18-60 years of age, and a PANSS total score of 80-120. A total of 446 subjects were randomized to one of the following treatment arms: cariprazine $3.0-6.0 \mathrm{mg} /$ day, cariprazine $6.0-9.0 \mathrm{mg} /$ day, or placebo. Subjects were required to be hospitalized during the washout period and for the first 4 weeks of the double-blind treatment; afterwards they could be discharged from the hospital as determined by the site investigator and based on the patient's clinical status. A total of $39 \%$ of patients discontinued prematurely. Statistically significant improvement in PANSS total score was observed in each of the cariprazine dose groups relative to placebo. The change from baseline was statistically significant at every time point starting at week 1 for cariprazine $6.0-9.0 \mathrm{mg} /$ day and week 2 onward for cariprazine $3.0-6.0 \mathrm{mg} / \mathrm{day}$. The most common adverse events (incidence of at least 10\%) observed in any treatment group were akathisia, headache, insomnia, restlessness, and extrapyramidal disorder.

\section{LONG-TERM CLINICAL TRIALS}

Additional safety and tolerability data is available from a 48-week, open-label, extension study, RGH-MD-17 [41]. Subjects were required to have completed RGH-MD-16 [38] and be classified as a responder (defined as having a CGI-S score no greater than 3 and a reduction in their PANSS total score of at least $20 \%$ relative to baseline), and be stable and eligible to continue as outpatients. Exclusion criteria included ongoing, uncontrolled, clinically significant adverse events or extrapyramidal symptoms not adequately controlled by medication; or clinically significant abnormal vital signs, clinical laboratory values, ECG results, ophthalmology assessment, or physical examination. There was a medicationfree screening period of up to 7 days. Cariprazine was initiated at $1.5 \mathrm{mg} /$ day and up-titrated in $1.5-\mathrm{mg}$ dose increments to a maximum of $4.5 \mathrm{mg} /$ day, depending on response and tolerability. The dose could be decreased at any time if tolerability issues arose. A total of 97 subjects were enrolled in the extension study and 93 patients received at least one dose of cariprazine (safety population). Of the 93 subjects in the safety population, 53 subjects had been randomized to cariprazine in the lead-in study compared to 15 to placebo, 
and 25 to risperidone. Mean age was 34.5 years; male gender 68\%; white race 56\%; mean BMI $25.0 \mathrm{~kg} / \mathrm{m}^{2}$. A total of $50.5 \%$ discontinued the trial prematurely; reasons include withdrawal of consent (17.2\% of all subjects), adverse events $(10.8 \%)$, protocol violation $(9.7 \%)$, lost to follow-up $(7.5 \%)$, insufficient therapeutic response (3.2\%), and other reasons (2.2\%). Mean duration of treatment was 222 days. Cariprazine $4.5 \mathrm{mg} /$ day was the final dose for $70 \%$ of the subjects and the model dose for $68 \%$. The most common treatment-emergent adverse events (incidence of at least 10\%) were akathisia (14\%), insomnia (14\%), and weight gain (12\%). Mean changes in clinical laboratory values were generally small. There was no signal for treatment-emergent hepatic abnormalities. Mean prolactin levels decreased from baseline. No clinically significant trends or changes were noted on most metabolic variables, but insulin showed an increasing trend from baseline. Mean body weight increased by $1.87 \mathrm{~kg}$ from a lead-in baseline mean of $71.26 \mathrm{~kg}$. Increase in weight of at least $7 \%$ from baseline was observed in 33\% of subjects; decrease in weight by at least $7 \%$ from baseline was observed in $8 \%$ of subjects. Although mean and median changes in blood pressure and pulse rate parameters were small, orthostatic hypotension while changing from the supine to standing position were noted in $25 \%$ of subjects. No signal was observed for abnormalities in the ECG QT interval. The rate of treatment-emergent parkinsonism (Simpson Angus Scale total score $>3$ ) was $8.6 \%$ and was similar to the rate observed for cariprazine in the lead-in study (8.2$10.3 \%)[38,41]$. The rate of treatment-emergent akathisia (Barnes Akathisia Scale score $>2$ ) was $17.2 \%$ and was higher than the rate observed in the lead-in study (11.0-15.1\%) [38, 41]. There were no discontinuations because of treatmentemergent movement disorder-related adverse events. There were no treatment-emergent adverse events related to suicidal ideation or behavior. There was no signal for treatmentemergent ophthalmological abnormalities.

\section{RANDOMIZED CONTROLLED TRIALS IN PROGRESS}

Table 1 notes an ongoing trial, RGH-MD-06, a long-term relapse prevention study [40]. As per the study registration on the ClinicalTrials.gov website, subjects with schizophrenia, 18-60 years of age, and with a PANSS total score between 70 and 120 are eligible, and would receive cariprazine $3.0-9.0 \mathrm{mg} /$ day during an open-label phase prior to randomization to cariprazine or placebo. The study is being conducted internationally.

\section{OVERALL PLACE OF CARIPRAZINE IN THERAPY}

Cariprazine represents a new treatment option for schizophrenia. Efficacy was established in the dose range of $1.5-9.0 \mathrm{mg} /$ day $[38,39]$ and tolerability within the dose range of 1.5-12.0 mg/day [37-39]. There do not appear to be clinically relevant adverse effects of cariprazine on metabolic variables, prolactin, or the ECG QT interval. In the fixeddose study of cariprazine that tested 1.5, 3.0, and $4.5 \mathrm{mg} /$ day, the most commonly encountered adverse events were insomnia, extrapyramidal disorder, sedation, akathisia, nausea, dizziness, vomiting, anxiety, and constipation [38]. However, the differences in incidence versus placebo for these events were generally small. Detailed data regarding tolerability for doses greater than $4.5 \mathrm{mg} /$ day, as used in the two positive phase 3 studies [39], have not yet been presented. Additional controlled long-term data is desirable to further characterize any longerterm treatment-related changes in body weight, metabolic variables, and movement disorders.

A recommendation in product labeling for dose titration will likely mirror that used in the 
clinical trials, otherwise dosing is once daily without regard to meals. When comparing cariprazine with the commercially available, "metabolically-friendly," second-generation antipsychotics, cariprazine most resembles aripiprazole (see Table 3) [38, 43-48].

Cariprazine is a potential alternative to aripiprazole [44, 49]. Although both cariprazine and aripiprazole are dopamine receptor partial agonists, cariprazine has a different receptor binding profile, with greater affinity for the dopamine D3 receptor as the main distinguishing feature. Whether this would be clinically relevant requires additional randomized controlled trials that are specifically designed and powered to contrast cariprazine with aripiprazole at optimal doses. Regarding the latter, it is unclear which doses of cariprazine would offer the best balance in terms of efficacy and tolerability. Moreover, the presence of the active metabolite, didesmethyl-cariprazine, with a half-life of 3 weeks, provides an opportunity to test different dosing regimens, such as once-weekly oral administration.

Whether or not cariprazine has pro-cognitive effects and/or ameliorates negative symptoms in persons with schizophrenia through action at

Table 3 Highlights of differences and similarities among cariprazine, ziprasidone, aripiprazole, iloperidone, asenapine, and lurasidone regarding their adverse event profiles in acute schizophrenia in adults as reported in product labeling and available information for cariprazine from RGH-MD-16 [38]

\begin{tabular}{|c|c|c|c|c|c|c|}
\hline & $\begin{array}{l}\text { Cariprazine } \\
{[38]}\end{array}$ & $\begin{array}{l}\text { Ziprasidone } \\
{[43]}\end{array}$ & $\begin{array}{l}\text { Aripiprazole } \\
{[44]}\end{array}$ & $\begin{array}{l}\text { Iloperidone } \\
{[45]}\end{array}$ & $\begin{array}{l}\text { Asenapine } \\
{[46]}\end{array}$ & $\begin{array}{l}\text { Lurasidone } \\
{[47]}\end{array}$ \\
\hline $\begin{array}{l}\text { Spontaneous AE } \\
\text { with incidence } \geq 5 \% \\
\text { and twice placebo }\end{array}$ & $\begin{array}{l}\text { Insomnia, } \\
\text { extrapyramidal } \\
\text { disorder, sedation, } \\
\text { akathisia, } \\
\text { nausea, dizziness, } \\
\text { vomiting, anxiety, } \\
\text { and constipation }\end{array}$ & $\begin{array}{l}\text { Somnolence, } \\
\text { respiratory } \\
\text { tract infection }\end{array}$ & Akathisia & $\begin{array}{l}\text { Dizziness, } \\
\text { dry mouth, } \\
\text { fatigue, nasal } \\
\text { congestion, } \\
\text { orthostatic } \\
\text { hypotension, } \\
\text { somnolence, } \\
\text { tachycardia, } \\
\text { and weight } \\
\text { gain }\end{array}$ & $\begin{array}{l}\text { Akathisia, oral } \\
\text { hypoesthesia, } \\
\text { and } \\
\text { somnolence }\end{array}$ & $\begin{array}{l}\text { Somnolence, } \\
\text { akathisia, } \\
\text { nausea, and } \\
\text { parkinsonism }\end{array}$ \\
\hline $\begin{array}{l}\mathrm{AE} \text { - somnolence, } \\
\mathrm{NNH}\end{array}$ & $20-50$ (sedation) & 15 & 20 & 16 & 17 & 10 \\
\hline $\begin{array}{l}\mathrm{AE} \text { - akathisia, } \\
\mathrm{NNH}\end{array}$ & $20-34$ & 100 & 25 & $\begin{array}{l}\text { Rate lower than } \\
\text { placebo }\end{array}$ & 33 & 10 \\
\hline $\begin{array}{l}\text { NNH weight gain } \\
\geq 7 \%\end{array}$ & $12-35$ & 17 & 20 & 12 & 35 & 67 \\
\hline Prolactin warning? & No & Yes & No & Yes & Yes & Yes \\
\hline QT warning? & No & Yes & No & Yes & Yes & No \\
\hline
\end{tabular}

Adapted with permission from Citrome L. Lurasidone in schizophrenia: new information about dosage and place in therapy. Adv Ther. 2012;29:815-25 [48]

$A E$ adverse event, $N N H$ number needed to harm 
the dopamine D3 or serotonin 5-HT1A receptor will require specifically designed clinical trials.

Cost will likely be a consideration given the availability of generic second-generation antipsychotics, including the future emergence of generic formulations of aripiprazole. The availability of a long-acting injectable formulation of aripiprazole may also factor into clinical decision making [50].

At present, available data are limited to trials with constrained inclusion/exclusion criteria that can limit their generalizability. Moreover, so far, none of the efficacy studies have been published in peer-reviewed journals, and so the data presented must be considered preliminary and subject to revision.

Logical candidates for cariprazine treatment would be adults with schizophrenia for whom metabolic or cardiovascular risk is a concern, and for whom weight gain is to be minimized or avoided. Patients who are sensitive to akathisia, nausea, and parkinsonism will need to be monitored for these adverse drug reactions.

\section{CONCLUSIONS}

If commercialized, cariprazine will be a new treatment option for schizophrenia. Based on the short-term studies conducted by the manufacturer, efficacy was established in the dose range of 1.5-9.0 mg/day and tolerability within the dose range of $1.5-12.0 \mathrm{mg} / \mathrm{day}$. There do not appear to be clinically relevant adverse effects of cariprazine on metabolic variables, prolactin, or the ECG QT interval. In the fixed-dose study of cariprazine that tested $1.5,3.0$, and $4.5 \mathrm{mg}$ /day, the most commonly encountered adverse events were insomnia, extrapyramidal disorder, sedation, akathisia, nausea, dizziness, vomiting, anxiety, and constipation. However, the differences in incidence versus placebo for these events were generally small. Information from a 48-week, open-label study provides tolerability data that is generally consistent with that from the available information from the short-term registration trials. Additional clinical trials are underway for the use of cariprazine in relapse prevention in schizophrenia, and in patients with bipolar disorder and major depressive disorder.

\section{ACKNOWLEDGMENTS}

No writing assistance was utilized in the production of this review. The manufacturer (Forest Laboratories Ltd.) had no substantive role in the creation of the manuscript but was offered the opportunity to comment on any possible inaccuracies prior to peer review. Dr. Citrome is the guarantor for this article, and takes responsibility for the integrity of the work as a whole.

Conflict of interest. In the past 36 months, Leslie Citrome has engaged in collaborative research with, or received consulting or speaking fees, from: Alexza, Alkermes, AstraZeneca, Avanir, Bristol-Myers Squibb, Eli Lilly, Forest, Genentech, Janssen, Lundbeck, Merck, Novartis, Noven, Otsuka, Pfizer, Shire, Sunovion, and Valeant.

\section{REFERENCES}

1. Volavka J, Citrome L. Oral antipsychotics for the treatment of schizophrenia: heterogeneity in efficacy and tolerability should drive decision-making. Expert Opin Pharmacother. 2009;10:1917-28.

2. Citrome L. Oral antipsychotic update: a brief review of new and investigational agents for the treatment of schizophrenia. CNS Spectr. 2012;17(Suppl. 1):1-9.

3. American Psychiatric Association. New Research Abstracts. $161^{\text {st }}$ Annual Meeting of the American Psychiatric Association; May 3-8, 2008; Washington, DC.

4. American Psychiatric Association. New Research Abstracts. 162 ${ }^{\text {nd }}$ Annual Meeting of the American Psychiatric Association; May 16-21, 2009; San Francisco, CA. 
5. American Psychiatric Association. New Research Abstracts. $163^{\text {rd }}$ Annual Meeting of the American Psychiatric Association; May 22-26, 2010; New Orleans, LA.

6. American Psychiatric Association. New Research Abstracts. $164^{\text {th }}$ Annual Meeting of American Psychiatric Association; May 14-18, 2011; Honolulu, HI.

7. American Psychiatric Association. New Research Abstracts. $165^{\text {th }}$ Annual Meeting of the American Psychiatric Association; May 5-9, 2012; Philadelphia, PA.

8. American Psychiatric Association. Syllabus and Proceedings Summary. $60^{\text {th }}$ Institute on Psychiatric Services; October 2-5, 2008; Chicago, IL.

9. American Psychiatric Association. Syllabus and Proceedings Summary. $61^{\text {st }}$ Institute on Psychiatric Services; October 8-11, 2009; New York, NY.

10. American Psychiatric Association. Syllabus and Proceedings Summary. $62^{\text {nd }}$ Institute on Psychiatric Services; October 14-17, 2010; Boston, MA.

11. American Psychiatric Association. Syllabus and Proceedings Summary. $63^{\text {rd }}$ Institute on Psychiatric Services; October 27-30, 2011; San Francisco, CA.

12. American Psychiatric Association. Syllabus and Proceedings Summary. $64^{\text {th }}$ Institute on Psychiatric Services; October 4-7, 2012; New York, NY.

13. National Institute of Mental Health and American Society of Clinical Psychopharmacology. Poster Abstracts. 48 ${ }^{\text {th }}$ Annual NCDEU Meeting; May 2730, 2008; Phoenix, AZ.

14. National Institute of Mental Health and American Society of Clinical Psychopharmacology. Poster

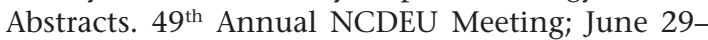
July 2, 2009; Hollywood, FL.

15. National Institute of Mental Health and American Society of Clinical Psychopharmacology. Poster Abstracts. 50 ${ }^{\text {th }}$ Annual NCDEU Meeting; June 1417, 2010; Boca Raton, FL.

16. American Society of Clinical Psychopharmacology. Poster Abstracts. 51 $1^{\text {st }}$ Annual NCDEU Meeting; June 14-17, 2011; Boca Raton, FL.

17. American Society of Clinical Psychopharmacology. Poster Abstracts. 52 ${ }^{\text {nd }}$ Annual NCDEU Meeting; May 29-June 1, 2012; Phoenix, AZ.

18. American College of Neuropsychopharmacology. $47^{\text {th }}$ Annual Meeting; December 7-11, 2008; Scotsdale, AZ.
19. American College of Neuropsychopharmacology. $48^{\text {th }}$ Annual Meeting; December 6-10, 2009; Hollywood, FL.

20. American College of Neuropsychopharmacology. 49 ${ }^{\text {th }}$ Annual Meeting; December 5-9, 2010; Miami Beach, FL.

21. American College of Neuropsychopharmacology. $50^{\text {th }}$ Annual Meeting; December 4-8, 2011; Waikoloa Beach, HI.

22. Citrome L. Cariprazine in bipolar disorder: clinical efficacy, tolerability, and place in therapy. Adv Ther. 2013;30:102-13.

23. Citrome L. Cariprazine: chemistry, pharmacodynamics, pharmacokinetics and metabolism, clinical efficacy, safety and tolerability. Expert Opin Drug Metab Toxicol. 2013;9:193-206.

24. Kiss B, Horváth A, Némethy Z, et al. Cariprazine (RGH$188)$, a dopamine $\mathrm{D}(3)$ receptor-preferring, $\mathrm{D}(3) / \mathrm{D}(2)$ dopamine receptor antagonist-partial agonist antipsychotic candidate: in vitro and neurochemical profile. J Pharmacol Exp Ther. 2010;333:328-40.

25. Sokoloff P, Diaz J, Le Foll B, et al. The dopamine D3 receptor: a therapeutic target for the treatment of neuropsychiatric disorders. CNS Neurol Disord Drug Targets. 2006;5:25-43.

26. Zimnisky R, Chang G, Gyertyán I, Kiss B, Adham $\mathrm{N}$, Schmauss C. Cariprazine, a dopamine $\mathrm{D}(3)$ receptor-preferring partial agonist, blocks phencyclidine-induced impairments of working memory, attention set-shifting, and recognition memory in the mouse. Psychopharmacology (Berl). 2012 [Epub ahead of print].

27. Gyertyán I, Kiss B, Sághy $\mathrm{K}$, et al. Cariprazine (RGH-188), a potent D3/D2 dopamine receptor partial agonist, binds to dopamine D3 receptors in vivo and shows antipsychotic-like and procognitive effects in rodents. Neurochem Int. 2011;59:925-35.

28. Auclair AL, Cathala A, Sarrazin F, et al. The central serotonin 2B receptor: a new pharmacological target to modulate the mesoaccumbens dopaminergic pathway activity. J Neurochem. 2010;114:1323-32.

29. Newman-Tancredi A, Kleven MS. Comparative pharmacology of antipsychotics possessing combined dopamine D2 and serotonin 5-HT1A receptor properties. Psychopharmacology (Berl). 2011;216:451-73.

30. Newman-Tancredi A. The importance of 5-HT1A receptor agonism in antipsychotic drug action: rationale and perspectives. Curr Opin Investig Drugs. 2010;11:802-12. 
31. Keator DB, Mukherjee J, Preda A, et al. Dopamine D2 and D3 receptor occupancy of cariprazine in schizophrenic patients. Schizophr Bull. 2009;35(Suppl. 1):154.

32. Potkin S, Keator D, Mukherjee J, et al. Dopamine D3 and D2 receptor occupancy of cariprazine in schizophrenic patients. Eur Neuropsychopharmacol. 2009;19(Suppl. 3):S316.

33. Meszaros GP, Kapas $M$, Borsos $M$, et al. Pharmacokinetics of RGH-188, a new dopamine D3/ D2 antagonist/partial agonist atypical antipsychotic, in healthy subjects. Eur Neuropsychopharmacol. 2007;217(Suppl. 4):S451-2.

34. Ereshefsky L, Gage A, Yu B, et al. Phase I study of RGH-188 in schizophrenic patients. Poster Presentation NR4-61, American Psychiatric Association $161^{\text {st }}$ Annual Meeting; May 3-8, 2008; Washington, DC.

35. Kapas M, Meszaros GP, Yu B, et al. Comparison of the pharmacokinetic behaviour of RGH-188 in schizophrenic patients and healthy volunteers. Eur Neuropsychopharmacol. 2008;18(Suppl. 4):433.

36. Kirschner $\mathrm{N}$, Gemesi LI, Vastag $\mathrm{M}$, et al. In vitro metabolism of RGH-188. Drug Metab Rev. 2008;40(Suppl. 1):128-9.

37. Litman R, Papadakis K, Durgam S, Xie J. Use of cariprazine in the treatment of schizophrenia: a proofof-concept trial. Poster Presentation 61, 60 ${ }^{\text {th }}$ Institute on Psychiatric Services of the American Psychiatric Association; October 2-5, 2008; Chicago, IL.

38. Bose A, Li D, Migliore R, et al. The efficacy and safety of the novel antipsychotic cariprazine in acute exacerbation of schizophrenia. Poster Presentation I-73, NCDEU 50 ${ }^{\text {th }}$ Annual Meeting; June 14-17, 2010; Boca Raton, FL.

39. Forest Laboratories, Inc. and Gedeon Richter Plc. Announce Results from Two Positive Phase III Trials with the Investigational Antipsychotic Cariprazine for the Treatment of Schizophrenia [press release]. Forest Laboratories, Inc.; February 28 2012. Available at: http://news.frx.com/press-release/rd-news/forestlaboratories-inc-and-gedeon-richter-plc-announceresults-two-positive-p. Accessed November 62012.

40. Cariprazine Relative to Placebo in the Prevention of Relapse of Symptoms in Patients With Schizophrenia. Forest Laboratories, Inc. Available at: http://clinicaltrials.gov/ct2/show/ NCT01412060. Accessed November 62012.
41. Cutler A, Bose A, Durgam S, et al. Safety and tolerability of cariprazine in the long-term treatment of schizophrenia: results from a 48-week extension study. Poster Presentation NR650, American Psychiatric Association 165th Annual Meeting; May 5-9, 2012; Philadelphia, PA.

42. Safety, pharmacokinetics and efficacy study of MP214 in patients with schizophrenia. Mitsubishi Tanabe Pharma Corporation. Available at: http://clinicaltrials.gov/ct2/show/NCT00862992. Accessed November 62012.

43. Geodon (ziprasidone) [product information]. Pfizer; revised October 2012. Available at: http:// labeling.pfizer.com/ShowLabeling. aspx?id=584. Accessed January 112013.

44. Abilify (aripiprazole) [product information]. Otsuka Pharmaceutical Co.; revised February 2012. Available at: http://www.abilify.com/pdf/pi.aspx. Accessed November 122012.

45. Fanapt (iloperidone) [product information]. Novartis Pharmaceuticals Corporation.; revised January 2012. Available at: http://www.pharma.us.novartis.com/product/pi/ pdf/fanapt.pdf. Accessed January 152013.

46. Saphris (asenapine) [product information]. Merck \& Co.; revised October 2012. Available at: http://www.merck.com/product/usa/pi_circulars/s/ saphris/saphris_pi.pdf. Accessed January 112013.

47. Latuda (lurasidone) [product information]. Sunovion Pharmaceuticals Inc.; revised May 2012. Available at: http://latudahcp.com/ LatudaPrescribingInformation.pdf. Accessed September 52012.

48. Citrome L. Lurasidone in schizophrenia: new information about dosage and place in therapy. Adv Ther. 2012;29:815-25.

49. Citrome L. A review of aripiprazole in the treatment of patients with schizophrenia or bipolar I disorder. Neuropsychiatr Dis Treat. 2006;2:42743.

50. Kane JM, Sanchez R, Perry PP, et al. Aripiprazole intramuscular depot as maintenance treatment in patients with schizophrenia: a 52week, multicenter, randomized, double-blind, placebo-controlled study. J Clin Psychiatry. 2012;73:617-24. 